\title{
Interaction effect of irrigation scheduling, mulching and integrated nutrient management on summer groundnut (Arachis hypogaea L.) yields under subtropical conditions of eastern Uttar Pradesh
}

\section{Avinash Chandra Maurya}

Department of Agronomy, Institute of Agricultural Sciences, Banaras Hindu University, Varanasi-221005 (Uttar Pradesh), India

Sunil Kumar Verma

Department of Agronomy, Institute of Agricultural Sciences, Banaras Hindu University, Varanasi-221005 (Uttar Pradesh), India

\section{Sushil Kumar*}

ICAR-Central Arid Zone Research Institute, Regional Research Station, Kukma-370105, Bhuj (Gujarat), India

Kairovin Lakra

Chandra Sekhar Azad University of Agriculture and Technology, Kanpur-208002 (Uttar Pradesh), India

*Corresponding author. E-mail: sushilangrau@gmail.com

\begin{abstract}
The study aimed to evaluate the interaction effect of irrigation scheduling, mulching and integrated nutrient management on yields of summer groundnut under sub-tropical conditions. An experiment of summer groundnut involving three irrigation scheduling, two mulching and four integrated nutrient management treatments was undertaken for consecutive two years at Agricultural Research Farm, Institute of Agricultural Sciences, Banaras Hindu University, Varanasi, India in a split-plot design with three replications Treatments significantly influenced pod, kernel, haulm, and biological yield of groundnut. Irrigation scheduling at $60 \mathrm{CPE}$ (cumulative pan evaporation) with paddy straw mulch and $75 \%$ recommended dose of nitrogen (RDN) $+25 \% \mathrm{~N}$ through farmyard manure $(\mathrm{FYM})]+60$ $\mathrm{kg} \mathrm{S}$ through gypsum recorded highest pod $\left(3611 \mathrm{~kg} \mathrm{ha}^{-1}\right)$, kernel $\left(2254 \mathrm{~kg} \mathrm{ha}^{-1}\right)$, haulm $\left(5185 \mathrm{~kg} \mathrm{ha}^{-1}\right)$, and biological yield $\left(8743 \mathrm{~kg} \mathrm{ha}^{-1}\right)$. Further this treatment combination was found better for increasing summer groundnut yields under subtropical conditions.
\end{abstract}

Keywords: Biological yield, Haulm yield, Kernel yield, Pod yield, Summer groundnut

\section{INTRODUCTION}

India is one of the largest producers of oilseeds in the world accounting for $8 \%$ of the global oilseeds production with $14 \%$ world land area and notified as second largest producer of groundnut (Meena et al., 2011). Groundnut is used as oil and food crop grown mainly in kharif and summer season especially in light textured soils. In India, groundnut is cultivated in an area of 4.56 million hectares (M ha) with 6.77 million tonnes (Mt) production at $1486 \mathrm{~kg} \mathrm{ha}{ }^{-1}$ productivity (MOA and FW, 2016).Uttar Pradesh with $0.10 \mathrm{M}$ ha area, $0.07 \mathrm{Mt}$ production at $670 \mathrm{~kg} \mathrm{ha}^{-1}$ productivity is ranked $10^{\text {th }}$ most important among groundnut growing states in India(MOA and FW, 2016). The productivity of groundnut in Uttar Pradesh is low as compared to national average might be due to cultivation of groundnut crop mostly under moisture stress conditions and imbalanced fertilization with non-application of secondary nutrients viz., Ca and S. Optimum scheduling of irrigation increases

\section{Article Info}

DOI:10.31018/jans.v11i2.2069

Received: April 19, 2019

Revised: May 16, 2019

Accepted: May 22, 2019

\section{How to Cite}

Maurya, A. C. et al. (2019). Interaction effect of irrigation scheduling, mulching and integrated nutrient management on summer groundnut (Arachis hypogaea L.) yields under subtropical conditions of eastern Uttar Pradesh. Journal of Applied and Natural Science, 11(2): $384-387$ https:// doi.org/10.31018/ jans.v11i2.2069 pod yield due to proper moisture condition in the rhizosphere which affects the nodulation as well as availability of different nutrients (Das et al.,2013). Combination of irrigation with mulches has been found better for water uptake by the crop and to reduce the frequency of irrigation. Besides, increasing water uptake and reducing irrigation frequency, mulches also help in maintaining optimum moisture and thermal environment of soil. It also increases water use efficiency through reduction in evaporation and subsequently results in higher kernel yield (Chakraborty et al.,2008).The supply of nutrients to groundnut through integrated nutrient management (INM) along with gypsum is beneficial in boosting the crop performance as gypsum provides $\mathrm{Ca}$ and $\mathrm{S}$, essential nutrients mainly responsible for enhancing pod yield and quality, while organic and inorganic sources of nutrient given through INM provide favourable nutritional environment (Karunakaran et al., 2010) with positive effects on 
soil physico-chemical properties. The information on above aspects, especially in summer groundnut is meagre in the eastern parts of Uttar Pradesh. Hence a study was undertaken to evaluate the effects of irrigation scheduling, mulching and INM on summer groundnut (Arachis hypogaea L.) yields in subtropical conditions of Uttar Pradesh.

\section{MATERIALS AND METHODS}

A field experiment was conducted at Agricultural Research Farm, Institute of Agricultural Sciences, Banaras Hindu University (BHU), Varanasi $\left(23^{\circ}\right.$ $20^{\prime} \mathrm{N}$ latitude; $83^{\circ} 03^{\prime} \mathrm{E}$ longitude; at an altitude of $128.93 \mathrm{~m}$ above the mean sea-level) during summer seasons of 2015 and 2016. Varanasi experiences sub-tropical climate with hot dry summers and cold winters. Physico-chemical analysis showed that soil of the experimental site was sandy clay loam in texture having alkaline $\mathrm{pH}$ (7.86), low in available nitrogen (206.9 kg ha-1) and available phosphorus $\left(17.8 \mathrm{~kg} \mathrm{ha}^{-1}\right)$ and medium in available potassium (233.1 kg ha ${ }^{-1}$ ) and sulphur $\left(15.6 \mathrm{~kg} \mathrm{ha}^{-1}\right)$, respectively. The field was under rice-wheat cropping system (RWCS) for continuously five years (2011-2015) period before this experiment. The experiment had twenty-four treatment combinations viz. 6 combinations of three irrigation schedules $(60,80$ and $100 \mathrm{~mm}$ cumulative pan evaporation (CPE) and two mulch treatments (paddy straw mulch and dust mulch) in main plots and four INM levels $(100 \% \mathrm{~N}, 75 \% \mathrm{~N}+$ $25 \% \mathrm{~N}(\mathrm{FYM})+20 \mathrm{~kg} \mathrm{~S}$ through gypsum, $75 \% \mathrm{~N}+$ $25 \% \mathrm{~N}$ (vermicompost) $+40 \mathrm{~kg} \mathrm{~S}$ through gypsum and $75 \% \mathrm{~N}+25 \% \mathrm{~N}$ (FYM) $+60 \mathrm{~kg} \mathrm{~S}$ (gypsum) in sub-plots and was laid-out in a split-plot design with three replications. Groundnut variety 'HG 37' was sown at a spacing of $30 \times 10 \mathrm{~cm}$ on 25 and 10 March in 2015 and 2016, respectively. As per the treatments, paddy straw mulch $\left(10 \mathrm{t} \mathrm{ha}^{-1}\right)$ was evenly spread only in the inter-row spaces at 15 days after sowing (DAS) and dust mulching after all irrigations was maintained by manipulating soil surface with the help of spade. The entire quantity of nutrients except gypsum was applied in rows as basal application. The whole quantity of gypsum was applied at peg initiation stage. To keep irriga- tion frequency constant, a pre-determined quantity of water was applied by using Parshall flume and CPE was worked out from the daily Epan data taken from institute observatory and accordingly crop was irrigated (6 cm depth) at 60,80 , and 100 $\mathrm{CPE}$. The need-based crop management practices throughout the crop growing period were also followed to keep the crop in vigorous condition. Observations were recorded for yields (pod, kernel haulm, and biological) at harvest. When about $70 \%$ of haulms were dry, the crop was harvested from net plot area on 29 and 20 May in 2015 and 2016, respectively. Net plot yields (Pod, haulm, kernel, and biological yield) were recorded and converted into $\mathrm{kg} \mathrm{ha}^{-1}$ by adopting standard computation procedure. The data recorded from the experiment were analyzed as per the procedure described by Gomez and Gomez (1984) for splitplot design. Critical difference (CD) was calculated at $5 \%$ probability level for comparing treatments mean.

\section{RESULTS AND DISCUSSION}

The interaction of irrigation scheduling, mulching, and INM significantly $(P=0.05)$ influenced pod, kernel, haulm, and biological yield of groundnut (Table 1, 2, 3 and 4). The highest (3611 kg ha-1) and lowest (2405 kg ha-1) pod yield was recorded with $60 \mathrm{~mm}$ CPE with paddy straw mulch and $75 \%$ $\mathrm{RDN}+25 \% \mathrm{~N}(\mathrm{FYM})+60 \mathrm{~kg} \mathrm{~S}$ (gypsum) and 100 $\mathrm{mm}$ CPE with dust mulch and $100 \% \mathrm{RDN}$, respectively. The treatment combination of $60 \mathrm{~mm} \mathrm{CPE}$ with paddy straw mulch and $75 \% \mathrm{RDN}+25 \% \mathrm{~N}$ (FYM) + $60 \mathrm{~kg} \mathrm{~S}$ (gypsum) recorded $4-50 \%$ higher pod yield over rest of the treatment combinations (Table 1).

Further, the kernel $\left(2254 \mathrm{~kg} \mathrm{ha}^{-1}\right)$, haulm $(5185 \mathrm{~kg}$ $\left.\mathrm{ha}^{-1}\right)$, and biological $\left(8743 \mathrm{~kg} \mathrm{ha}^{-1}\right)$ yield were significantly higher in $60 \mathrm{~mm}$ CPE with paddy straw mulch and $75 \%$ RDN $+25 \% \mathrm{~N}(\mathrm{FYM})+60 \mathrm{~kg} \mathrm{~S}$ (gypsum) as compared to other treatment combinations. Furthermore, the combination of $60 \mathrm{~mm}$ CPE with paddy straw mulch and $75 \%$ RDN + $25 \% \mathrm{~N}(\mathrm{FYM})+60 \mathrm{~kg} \mathrm{~S}$ (gypsum) increased kernel $\left(2254 \mathrm{~kg} \mathrm{ha}^{-1}\right)$, haulm $\left(5185 \mathrm{~kg} \mathrm{ha}^{-1}\right)$, and biological $\left(8743 \mathrm{~kg} \mathrm{ha}^{-1}\right)$ yield in the proportion of 4-

Table 1. Interaction effect of irrigation scheduling, mulching and integrated nutrient management on summer groundnut pod yield $\left(\mathrm{kg} \mathrm{ha}^{-1}\right)$.

\begin{tabular}{|c|c|c|c|c|c|}
\hline \multirow[b]{2}{*}{ Treatment } & \multicolumn{5}{|c|}{ Integrated nutrient management } \\
\hline & $\begin{array}{l}100 \% \\
\text { RDN }\end{array}$ & $\begin{array}{c}75 \% \text { RDN + } 25 \% \\
\text { N (FYM) + } 20 \\
\text { kg S (gypsum) }\end{array}$ & $\begin{array}{l}75 \% \text { RDN + 25\% N } \\
\text { (Vermicompost) + } \\
40 \text { kg S (gypsum) }\end{array}$ & $\begin{array}{c}75 \% \text { RDN + } 25 \% \\
\text { N (FYM) + } 60 \text { kg } \\
\text { S (gypsum) }\end{array}$ & $\begin{array}{c}\text { Mean } \\
\text { Groundnut } \\
\text { pod yield }\end{array}$ \\
\hline Paddy straw mulch x 60 mm CPE & 3013 & 3227 & 3395 & 3611 & 3311 \\
\hline Paddy straw mulch $\times 80 \mathrm{~mm}$ CPE & 2758 & 2952 & 3131 & 3322 & 3041 \\
\hline Paddy straw mulch x 100 mm CPE & 2634 & 2820 & 2991 & 3223 & 2917 \\
\hline Dust mulch x $60 \mathrm{~mm} \mathrm{CPE}$ & 2893 & 3048 & 3259 & 3467 & 3167 \\
\hline Dust mulch x $80 \mathrm{~mm} \mathrm{CPE}$ & 2561 & 2750 & 2922 & 3025 & 2814 \\
\hline Dust mulch x $100 \mathrm{~mm}$ CPE & 2405 & 2559 & 2775 & 2924 & 2666 \\
\hline Mean & 2711 & 2892 & 3079 & 3262 & \\
\hline SEm \pm & & & 32.1 & & \\
\hline$C D(P=0.05)$ & & & 96.2 & & \\
\hline
\end{tabular}


Table 2. Interaction effect of irrigation scheduling, mulching and integrated nutrient management on summer groundnut kernel yield $\left(\mathrm{kg} \mathrm{ha}^{-1}\right)$.

\begin{tabular}{|c|c|c|c|c|c|}
\hline \multirow[b]{2}{*}{ Treatment } & \multicolumn{5}{|c|}{ Integrated nutrient management } \\
\hline & $\begin{array}{c}100 \\
\% \\
\text { RDN } \\
\end{array}$ & $\begin{array}{c}75 \% \text { RDN + 25\% } \\
\text { N (FYM) + } 20 \text { kg } \\
\text { S (gypsum) }\end{array}$ & $\begin{array}{l}75 \% \text { RDN + 25\% N } \\
\text { (Vermicompost) + } \\
40 \text { Kg S (gypsum) }\end{array}$ & $\begin{array}{c}75 \% \text { RDN + } 25 \% \\
\text { N (FYM) + } 60 \text { kg } \\
\text { S (gypsum) }\end{array}$ & $\begin{array}{c}\text { Mean } \\
\text { Groundnut } \\
\text { kernel yield }\end{array}$ \\
\hline Paddy straw mulch x $60 \mathrm{~mm} \mathrm{CPE}$ & 1881 & 2014 & 2120 & 2254 & 2067 \\
\hline Paddy straw mulch $\times 80 \mathrm{~mm}$ CPE & 1723 & 1844 & 1956 & 2075 & 1899 \\
\hline Paddy straw mulch x 100 mm CPE & 1646 & 1762 & 1869 & 1983 & 1815 \\
\hline Dust mulch x 60 mm CPE & 1806 & 1904 & 2035 & 2165 & 1977 \\
\hline Dust mulch $\times 80 \mathrm{~mm} \mathrm{CPE}$ & 1598 & 1716 & 1823 & 1919 & 1764 \\
\hline Dust mulch $\times 100 \mathrm{~mm} \mathrm{CPE}$ & 1501 & 1598 & 1733 & 1825 & 1664 \\
\hline Mean & 1692 & 1806 & 1923 & 2037 & \\
\hline SEm \pm & & & 17.51 & & \\
\hline$C D(P=0.05)$ & & & 52.54 & & \\
\hline
\end{tabular}

Table 3. Interaction effect of irrigation scheduling, mulching and integrated nutrient management on summer groundnut haulm yield $\left(\mathrm{kg} \mathrm{ha}^{-1}\right)$.

\begin{tabular}{|c|c|c|c|c|c|}
\hline \multirow[b]{2}{*}{ Treatment } & \multicolumn{5}{|c|}{ Integrated nutrient management } \\
\hline & $\begin{array}{c}100 \\
\% \\
\text { RDN } \\
\end{array}$ & $\begin{array}{c}75 \% \text { RDN + 25\% } \\
\text { N (FYM) + } 20 \text { kg } \\
\text { S (gypsum) } \\
\end{array}$ & $\begin{array}{l}75 \% \text { RDN + 25\% N } \\
\text { (Vermicompost) + } \\
40 \text { kg S (Gypsum) }\end{array}$ & $\begin{array}{c}75 \% \text { RDN + } 25 \% \\
\text { N (FYM) + } 60 \text { kg } \\
\text { S (gypsum) } \\
\end{array}$ & $\begin{array}{c}\text { Mean } \\
\text { groundnut } \\
\text { haulm yield } \\
\end{array}$ \\
\hline Paddy straw mulch x $60 \mathrm{~mm}$ CPE & 4550 & 4704 & 4951 & 5185 & 4847 \\
\hline Paddy straw mulch $\times 80 \mathrm{~mm}$ CPE & 4108 & 4233 & 4252 & 4419 & 4253 \\
\hline Paddy straw mulch $\times 100 \mathrm{~mm}$ CPE & 3867 & 3977 & 4183 & 4289 & 4079 \\
\hline Dust mulch x $60 \mathrm{~mm}$ CPE & 3632 & 3664 & 4019 & 4193 & 3877 \\
\hline Dust mulch x $80 \mathrm{~mm}$ CPE & 3428 & 3799 & 3852 & 4084 & 3791 \\
\hline Dust mulch x 100 mm CPE & 3289 & 3303 & 3584 & 3708 & 3471 \\
\hline Mean & 3812 & 3947 & 4140 & 4313 & \\
\hline SEm \pm & & & 114.0 & & \\
\hline $\mathrm{CD}(\mathrm{P}=0.05)$ & & & 342.2 & & \\
\hline
\end{tabular}

Table 4. Interaction effect of irrigation scheduling, mulching and integrated nutrient management on summer groundnut biological yield $\left(\mathrm{kg} \mathrm{ha}^{-1}\right)$.

\begin{tabular}{|c|c|c|c|c|c|}
\hline \multirow[b]{2}{*}{ Treatments } & \multicolumn{5}{|c|}{ Integrated nutrient management } \\
\hline & $\begin{array}{c}100 \\
\% \\
\text { RDN } \\
\end{array}$ & $\begin{array}{c}75 \% \text { RDN + 25\% } \\
\text { N (FYM) + 20 } \\
\text { kg S (gypsum) }\end{array}$ & $\begin{array}{l}75 \% \text { NPK+ } 25 \% \text { N } \\
\text { (vermicompost) + } \\
40 \text { kg S (gypsum) }\end{array}$ & $\begin{array}{c}75 \% \text { RDN + 25\% } \\
\text { N (FYM) + } 60 \text { kg } \\
\text { S (gypsum) }\end{array}$ & $\begin{array}{c}\text { Mean ground- } \\
\text { nut biological } \\
\text { yield }\end{array}$ \\
\hline Paddy straw mulch x $60 \mathrm{~mm}$ CPE & 7518 & 7882 & 8295 & 8743 & 8109 \\
\hline Paddy straw mulch $\times 80 \mathrm{~mm}$ CPE & 6971 & 7300 & 7477 & 7852 & 7400 \\
\hline Paddy straw mulch x 100 mm CPE & 6501 & 6796 & 7175 & 7463 & 6984 \\
\hline Dust mulch x $60 \mathrm{~mm} \mathrm{CPE}$ & 6261 & 6781 & 7067 & 7497 & 6901 \\
\hline Dust mulch x $80 \mathrm{~mm}$ CPE & 6036 & 6222 & 6792 & 7118 & 6542 \\
\hline Dust mulch $\times 100 \mathrm{~mm} \mathrm{CPE}$ & 5850 & 6052 & 6507 & 6783 & 6298 \\
\hline Mean & 6523 & 6839 & 7219 & 7576 & \\
\hline SEm \pm & & & 135 & & \\
\hline$C D(P=0.05)$ & & & 387 & & \\
\hline
\end{tabular}

$50,13-57$ and $5-49 \%$, respectively over rest of the combinations (Table 2-4). The frequent irrigation, mulching with paddy straw and FYM based INM treatments might have helped in increasing the water holding capacity of soil following improvement in physico-chemical properties of soil which ultimately boosted the crop performance and increased yields of the crop. Karunakaran et al. (2010) have also reported higher pod and haulm yield of groundnut with application of organic manure in combination of recommended dose of nitrogen, while Patel et al.(2009) reported higher pod $\left(3784 \mathrm{~kg} \mathrm{ha}^{-1}\right)$ and haulm $\left(6040 \mathrm{~kg} \mathrm{ha}^{-1}\right)$ yield of groundnut with frequent irrigations $(40 \mathrm{~mm}$ CPE) applied based on CPE. Our results are also in congruence with the findings of Maurya et al. (2017) on moisture extraction pattern and productivity of summer groundnut.

\section{Conclusion}

On the basis of the findings of this experiment it is concluded that scheduling irrigation at $60 \mathrm{~mm}$ CPE with paddy straw mulch (10 $\left.\mathrm{tha}^{-1}\right)$ and $75 \% \mathrm{RDN}+$ $25 \% \mathrm{~N}(\mathrm{FYM})+60 \mathrm{~kg} \mathrm{~S}$ (gypsum) was optimum for higher pod, kernel, haulm and biological yield.It is also inferred that substitution of $25 \%$ nitrogen requirement of the crop through $\mathrm{FYM}$ along with gypsum, paddy straw mulch, and frequent irrigation might have helped in improving physicochemical properties and nutrient profile of the soil which ultimately boosted the crop performance.

\section{REFERENCES}

1. Chakraborty, D., Nagarajan, S., Aggarwal, P., Gupta, V.K., Tomar, R.K., Garg, R.N., Sahoo, R.N., Sarkar, A., Chopra, U.K., Sarma, S.K.S. and Kalra, N. (2008). Effect of mulching on soil and plant water 
Maurya, A. C. et al. / J. Appl. \& Nat. Sci. 11(2): 384- 387 (2019)

status, and the growth and yield of wheat (Triticum aestivum L.) in a semi-arid environment. Agricultural Water Management, 95:1323-1334.

2. Das, A.K., Nayak, B.R., Panigrahy, N., Mohapatra, S. and Samant, P.K. (2013). Performance of groundnut (Arachis hypogaea) under different levels of sulphur and irrigation.Indian Journal of Agronomy,58(4):578582.

3. Gomez, A.K. and Gomez, A.A. (1984). Statistical Procedures for Agricultural Research (2nd edn.). John Wiley and Sons. London, UK.

4. Karunakaran, V., Rammohan, J., Chellamuthu, V. and Poonghuzhalan, R. (2010). Effect of integrated nutrient management on the growth and yield of groundnut (Arachis hypogaea) in coastal region of Karaikal. Indian Journal of Agronomy,55(2): 128-132.

5. Maurya, A. C., Verma, S. K. and Kumar, S. (2017). Effect of irrigation regimes, mulching and nutrient management on moisture extraction pattern and productivity of summer groundnut (Arachis hypogaea L.). Frontiers in Crop Improvement, 5(Spl. : 208-211.

6. Meena, B.P., Kumawat, S.M. and Yadav, R.S. (2011). Effect of planting geometry and nitrogen management on groundnut (Arachis hypogaea) in loamy sand soil of Rajasthan. Indian Journal of Agricultural Sciences, 81(1):86-8.

7. MOA and FW. (2016). Agricultural Statistics at a Glance, Department of Agriculture, Cooperation and Farmers Welfare, DES, pp. 121-123.

8. Patel, G.N., Patel, P.T., Patel, P.H., Patel, D.M., Patel, D.K. and Patel, R.M. (2009). Yield attributes, yield, quality and uptake of nutrients by summer groundnut, (Arachis hypogaea L.) as influenced by sources and levels of sulphur under varying irrigation schedules. Journal of Oilseeds Research,26(2):119122. 